Vol 11, Special issue 3, 2018

\title{
ANALYSIS OF CORTISOL LEVEL AFTER HIGH-DOSE AND LONG-TERM PREDNISONE EXPOSURE IN CHILDREN WITH STEROID-SENSITIVE NEPHROTIC SYNDROME
}

\author{
NANI WIJAYANTI DN ${ }^{1 *}$, NUN ZAIRINA ${ }^{2}$, NINIK ASMANINGSIH ${ }^{3}$, YULISTIANI ${ }^{4}$
}

${ }^{1}$ Department of Pharmacy, Hang Tuah University, Surabaya, Java, Indonesia. ${ }^{2}$ Department of Pharmacy, Installation of Dr. Soetomo Teaching Hospital Surabaya, Surabaya, Java, Indonesia. ${ }^{3}$ Department of Pediatrics, Nephrology Division, Dr. Soetomo Teaching Hospital Surabaya, Surabaya, Java, Indonesia. Email: naniwijayantidn@gmail.com

Received: 15 February 2018, Revised and Accepted: 23 March 2018

ABSTRACT

Objective: The objective of this study is to analyze the cortisol levels in induction and alternate phases associated with the clinical manifestation in the developing of adrenal suppression.

Methods: An observational, longitudinal study which had been approved by the ethical committee of Dr. Soetomo Teaching Hospital Surabaya was conducted from June to October 2016. The cortisol levels were measured before induction phase ( $\mathrm{t}=0$ ), after induction phase ( $\mathrm{t}=1$ ), and after alternate phase ( $\mathrm{t}=2$ ). The venous blood samples were obtained in the morning at 08.00-09.00 am. The data were analyzed using student's t-test.

Results: A total of 15 patients were included, but 6 patients were excluded because of cross-reactivity with prednisone when using ADVIA Centaur Cortisol Assay. 9 patients (55.56\% boys) had a mean age $6-<12$ years old and $33.33 \%$ were initial attack and dependent steroid nephrotic syndrome. 8 of 9 patients had a normal cortisol level at baseline $(\mathrm{t}=0)$. The cortisol level decrement in the induction phase was $72.92 \%(11.79 \pm 10.66 \mathrm{mcg} / \mathrm{dL}-1.75 \pm 1.08 \mathrm{mcg} / \mathrm{dL})$ $\left.{ }^{*} \mathrm{p}=0.024\right)$. After alternate phase, the cortisol levels increased $417.60 \%$ (1.75 $\pm 1.08 \mathrm{mcg} / \mathrm{dL}$ to $5.95 \pm 3.33 \mathrm{mcg} / \mathrm{dL}\left({ }^{*} \mathrm{p}=0.007\right)$. The clinical manifestation as nausea/vomiting and abdominal distension only appeared in $11.11 \%$ of patients in the induction phase but not in the alternate phase.

Conclusions: Hypothalamus-pituitary-adrenal (HPA) axis suppression could develop after induction phase which was indicated by low cortisol levels. High-dose and long-term prednisone exposure decreased the cortisol levels reversibly. The clinical manifestation of adrenal suppression as weakness, nausea/vomiting, acute dehydration, and abdominal distension almost did not manifest in all patients.

Keywords: Cortisol, Nephrotic syndrome, Sensitive steroid nephrotic syndrome, Prednisone, High-dose prednisone, Long-term prednisone, Hypothalamus-pituitary-adrenal axis suppression, Children.

(C) 2018 The Authors. Published by Innovare Academic Sciences Pvt Ltd. This is an open access article under the CC BY license (http://creativecommons. org/licenses/by/4. 0/) DOI: http://dx.doi.org/10.22159/ajpcr.2018.v11s3.30031

\section{INTRODUCTION}

Nephrotic syndrome (NS) is a glomerular disease characterized by heavy protein urine $\left(\geq 40 \mathrm{mg} / \mathrm{m}^{2} / \mathrm{h}\right.$ or more than $50 \mathrm{mg} / \mathrm{kg} /$ day or dipstick $\geq 2+$ ), hypoalbuminemia $(\leq 2.5 \mathrm{~g} / \mathrm{dL}$ ), and edema and may accompanied by hypercholesterolemia ( $>200 \mathrm{mg} / \mathrm{dL}$ ) [1-5]. The incidence of this disease in America and Europe was occurred in 1-3/100,000 in children with the mean age of $<16$ years old. The cumulative incidence was $16 / 100,000$ with the ratio between boy and girl 3.8:1 [5,6]. In Indonesia, the prevalence of this disease was 6 cases per 100,000 children each year with the ratio between boy and girl 2:1 [1,4].

The regimen therapy of NS was prednisone of $60 \mathrm{mg} / \mathrm{m}^{2}$ or $2 \mathrm{mg} / \mathrm{kg} /$ day for 4 weeks or until remission (relapse) for 3-4 weeks followed by the alternate-day prednisone of $40 \mathrm{mg} / \mathrm{m}^{2}$ or $1.5 \mathrm{mg} / \mathrm{kg} /$ day for $4-12$ weeks. There was a difference among guidelines for the duration of prednisone therapy, some guidelines recommended longer prednisone therapy for 3-6 months including full dose, and alternating dose could decrease risk relapse than therapy for 2-3 months [4,5,7]. The main effect of high-dose and long-term prednisone was hypothalamus-pituitaryadrenal (HPA) axis suppression. It could suppress endogenous cortisol production through suppression adrenal cortex $[8,9]$.

The mechanism of HPA axis suppression was occurred by short- and long-loop feedback in corticotropin-releasing hormone (CRH) neuron. The suppression of CRH neuron decreased the production of $\mathrm{CRH}$ mRNA, CRH, and ACTH. The net result of HPA axis suppression was decreasing cortisol production level in the adrenal cortex, especially in fasciculate zone $[10,11]$. The adrenal cortex suppression caused acute and chronic adrenal insufficiency which indicated by acute dehydration, hypotension, hypoglycemia, altered mental status, fatigue/weakness, anorexia, nausea, vomiting, loss of appetite, weight loss, and abdominal pain [12-14]. The children with NS who exposure to prednisone could develop adrenal suppression. The recovery period of it was not completely determined, but it could last up to 1 year [15].

Study-related HPA axis suppression was conducted since 1965 by measuring cortisol level after giving synacthen test. The result showed HPA axis suppression which indicated by decrease cortisol level [16-18]. The current study conducted in children with NS showed that there were possibilities in developing HPA axis suppression which was indicated by decrease cortisol level and increasing risk relapse [19]. Another study with different regimens conducted in adult showed the same result as in children [20]. However, how far the effect of prednisone therapy in children with sensitive NS in Dr. Soetomo Teaching Hospital Surabaya has not been determined. Therefore, to monitor cortisol level during high dose and long term prednisone therapy in nephrotic syndrome is necessary.

\section{METHODS}

We conducted a prospective, observational, and longitudinal study from June to October 2016 at the Pediatric Nephrology Department of Dr. Soetomo Teaching Hospital Surabaya. We recruited 16 children who diagnosed as steroid-sensitive NS, aged $<18$ years old, and followed this study until finish. We excluded patients who diagnosed as steroidresistant NS and took prednisone $<24 \mathrm{~h}$. We dropped outpatient who changed diagnose during study, did not followed the study completely, 
Table 1: Baseline characteristics of nephrotic syndrome patients

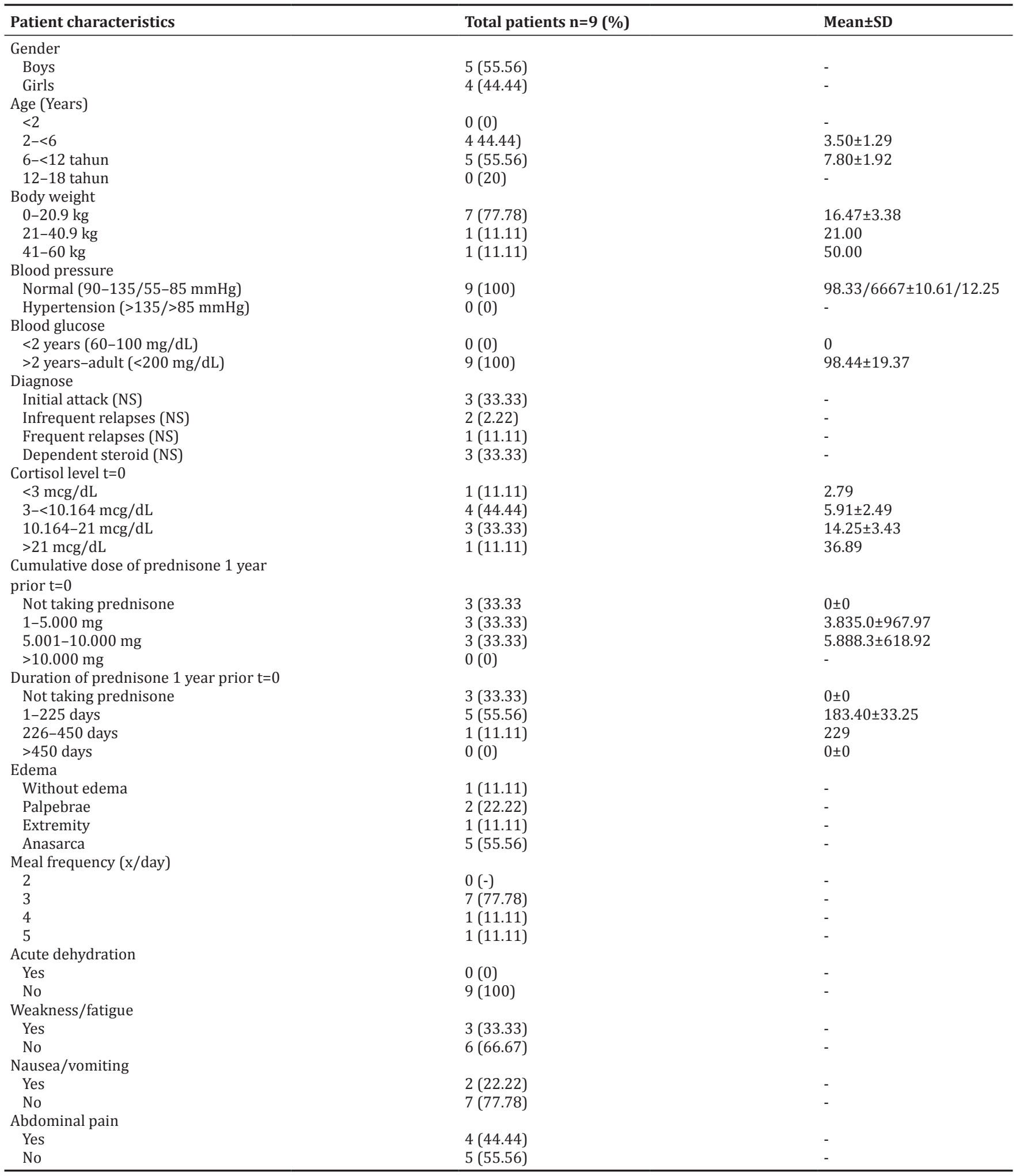

NS: Nephrotic syndrome

and died. Patients received full-dose prednisone of $2 \mathrm{mg} / \mathrm{kg} / \mathrm{day}$ or $60 \mathrm{mg} / \mathrm{m}^{2} /$ day for \pm 4 weeks and followed by alternate-day prednisone of $1.5 \mathrm{mg} / \mathrm{kg} /$ day or $40 \mathrm{mg} / \mathrm{m}^{2}$ for \pm 4 weeks. The cortisol level measured before induction phase, after induction phase, and after alternating phase at 08.00-09.00 a.m.

This study had been approved by the ethical committee of Dr. Soetomo Teaching Hospital Surabaya. We had explained everything about this study in detail before starting. All data were collected from patient medication report and direct interview with patients. ADVIA Centaur Cortisol Assay was used to determine cortisol level.

Normality test performed in interval scale data using One-sample Kolmogorov-Smirnov. Student's t-test was used to compare the cortisol level in the induction phase and alternating phase. Statistical analysis was performed using the computer program package 
Table 2: Cortisol levels of nephrotic syndrome patients

\begin{tabular}{|c|c|c|c|c|c|c|}
\hline \multirow{2}{*}{$\begin{array}{l}\text { Inisial } \\
\text { pasien }\end{array}$} & \multirow{2}{*}{$\begin{array}{l}\text { Normal } \\
\text { value }(\mathrm{mcg} / \mathrm{dL})\end{array}$} & \multicolumn{5}{|c|}{ Cortisol levels (mcg/dL) } \\
\hline & & $\mathbf{t}=\mathbf{0}$ & $\mathbf{t}=\mathbf{1}$ & $\mathbf{t}=\mathbf{2}$ & $\Delta_{\mathrm{t}=1-\mathrm{t}=0}$ & $\Delta_{\mathrm{t}=2-\mathrm{t}=1}$ \\
\hline AM (G/3 y) & $3-21$ & 10.41 & 1.6 & 3.12 & -8.81 & 1.52 \\
\hline $\mathrm{KY}(\mathrm{B} / 2 \mathrm{y})$ & $3-21$ & 15.36 & 2.51 & 1.18 & -12.85 & -1.33 \\
\hline $\mathrm{JA}(\mathrm{G} / 7 \mathrm{y})$ & $3-21$ & 9.35 & 2.67 & 4.22 & -6.68 & 1.55 \\
\hline $\mathrm{MA}(\mathrm{B} / 7 \mathrm{y})$ & $3-21$ & 16.99 & 0.99 & 8.56 & -16 & 7.57 \\
\hline $\mathrm{AP}(\mathrm{B} / 11 \mathrm{y})$ & $3-21$ & 4.23 & 3.9 & 10.88 & -0.33 & 6.98 \\
\hline $\mathrm{ND}(\mathrm{B} / 4 \mathrm{y})$ & $3-21$ & 3.92 & 0.62 & 9.83 & -3.3 & 9.21 \\
\hline $\mathrm{RA}(\mathrm{B} / 6 \mathrm{y})$ & $3-21$ & 36.89 & 1.32 & 3.5 & -35.57 & 2.18 \\
\hline $\mathrm{DA}(\mathrm{G} / 5 \mathrm{y})$ & $3-21$ & 2.79 & 1.56 & 7.34 & -1.23 & 5.78 \\
\hline Mean \pm SD & & $11.79 \pm 10.66$ & $1.75 \pm 1.08$ & $5.95 \pm 3.33$ & $-10.03 \pm 10.87$ & $4.19 \pm 3.46$ \\
\hline
\end{tabular}

Table 3: Clinical and laboratory manifestation of adrenal suppression

\begin{tabular}{|c|c|c|c|c|c|c|c|c|c|c|}
\hline Patients' code & $\mathbf{A M}$ & DI & KY & JA & MA & AP & ND & RA & DA & Mean \pm SD \\
\hline \multirow[t]{3}{*}{ Blood glucose } & 96 & 99 & 126 & 107 & 63 & 87 & 102 & 122 & 84 & $98.44 \pm 19.37$ \\
\hline & 111 & 107 & 102 & 99 & 122 & 110 & 92 & 123 & 89 & $106.1 \pm 11.92$ \\
\hline & 117 & 117 & 112 & 103 & 109 & 113 & 123 & 112 & 128 & $114.89 \pm 7.44$ \\
\hline \multirow[t]{5}{*}{ Blood pressure } & $90 / 60$ & $90 / 60$ & $95 / 50$ & $100 / 70$ & $110 / 80$ & $120 / 90$ & $90 / 60$ & $90 / 60$ & $100 / 70$ & $98.33 \pm 10.61$ \\
\hline & & & & & & & & & & $66.67 \pm 12.25$ \\
\hline & $90 / 60$ & $90 / 60$ & $100 / 60$ & $90 / 60$ & $100 / 70$ & $120 / 70$ & $90 / 60$ & $90 / 60$ & $80 / 50$ & $94.44 \pm 11,30$ \\
\hline & & & & & & & & & & $61.11 \pm 6.01$ \\
\hline & & & & & & & & & & $63.33 \pm 8.66$ \\
\hline \multirow{3}{*}{ Body weight } & 12 & 20 & 12 & 18 & 20 & 50 & 16 & 17 & 21 & $20.70 \pm 11.47$ \\
\hline & 11 & 21 & 14 & 20 & 21 & 48 & 16 & 15 & 21 & $20.56 \pm 10.93$ \\
\hline & 11 & 24 & 14 & 20 & 21 & 49 & 16 & 15 & 22 & $21.22 \pm 11.24$ \\
\hline \multirow[t]{3}{*}{ Meal frequency } & 3 & 3 & 3 & 3 & 4 & 3 & 3 & 5 & 3 & $3.13 \pm 0.64$ \\
\hline & 6 & 6 & 5 & 5 & 7 & 4 & 6 & 6 & 5 & $5.4 \pm 0.74$ \\
\hline & 6 & 5 & 3 & 3 & 5 & 3 & 6 & 5 & 5 & $4.3 \pm 1.16$ \\
\hline
\end{tabular}

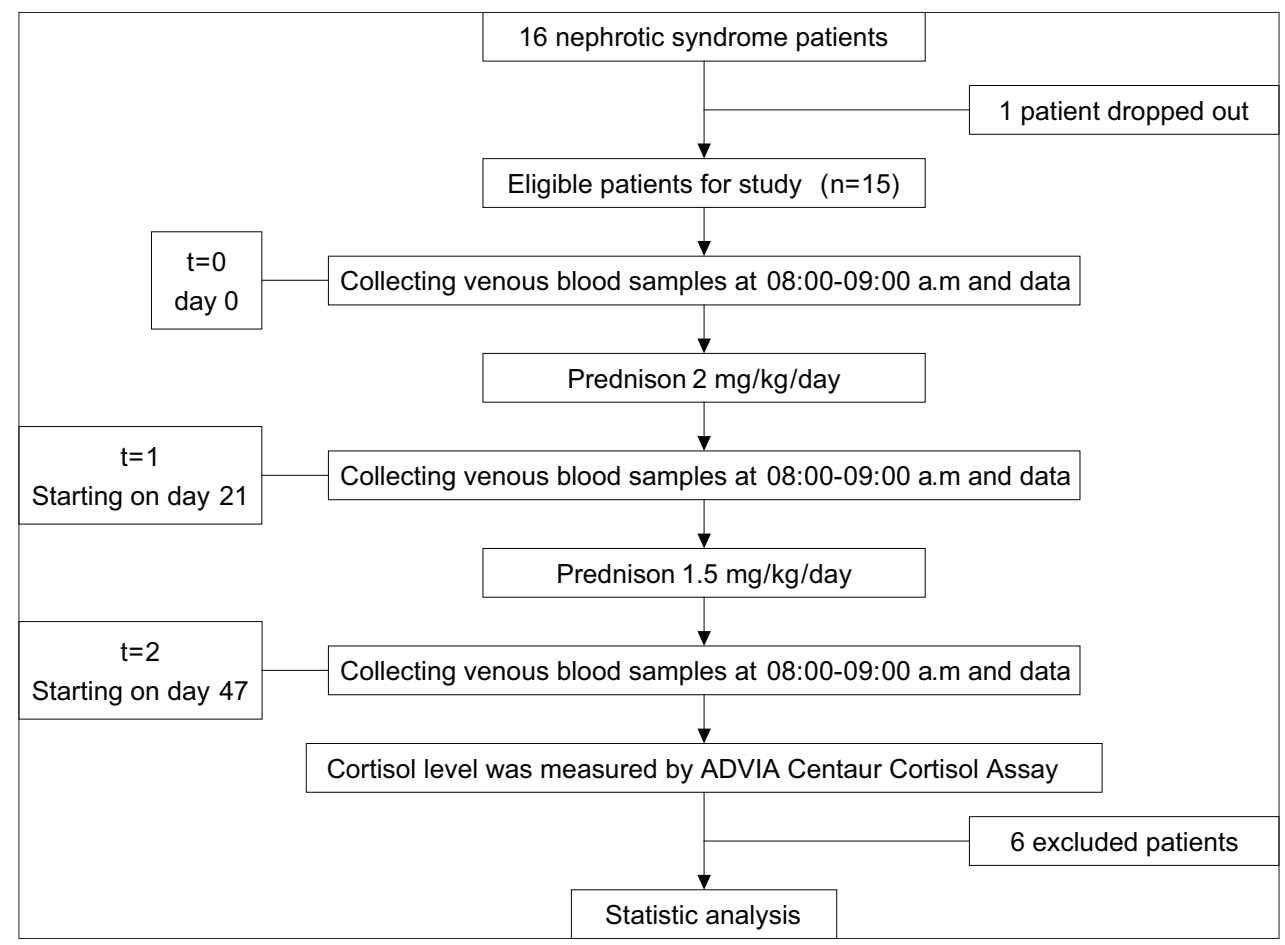

Fig. 1: Study flow chart

SPSS (version 20.0). Nominal data scale presented as a frequency distribution.

Overview of this cohort study was shown in Fig. 1.

\section{RESULTS}

The boy had higher percentage (55.56\%) than girl with the mean age of $6-<12$ years old $(55.56 \%)$. The mean weight was $16.47 \pm 3.38 \mathrm{~kg}$. 


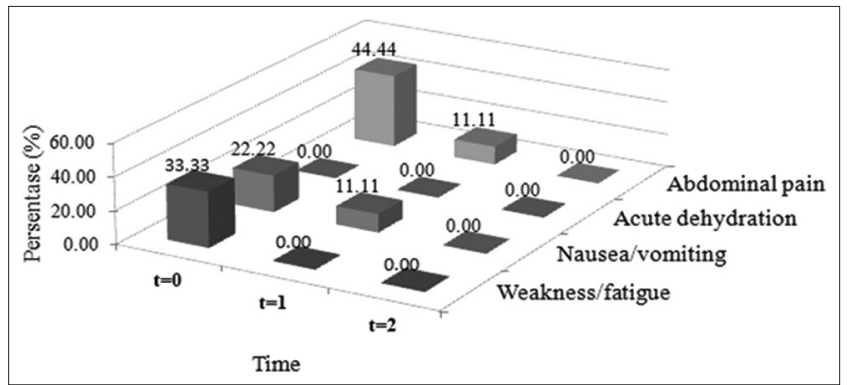

Fig. 2: Clinical manifestation of adrenal suppression

Based on diagnosis of patient, both initial attack and dependent steroid NS had the same percentage (33.33\%). History of duration and cumulative dose were determined as HPA axis suppression could last up to 1 year and relapse of infrequent relapse NS was $<4$ relapses in 1 year $[4,15]$. Baseline characteristics of all patients are showed in Table 1.

The majority cortisol level at $\mathrm{t}=0$ was normal $(44.44 \%)$, except one patient had cortisol subnormal $(<3 \mathrm{mcg} / \mathrm{dL})$ and one patient had the cortisol level higher than normal range $(>21 \mathrm{mcg} / \mathrm{dL})$. The cortisol level decreased into subnormal at $t=1$ and increased at the end of the alternating phase $(\mathrm{t}=2)$. However, AP still had normal cortisol level at $\mathrm{t}=1$. Table 2 shows the cortisol level of NS patients.

Statistical analysis of normality showed that all data were normally distributed. The duration and cumulative dose of prednisone a year before the study showed no correlation with the cortisol level at $\mathrm{t}=0$. Student's t-test to compare the cortisol level at $t=0$ and $t=1$ and $t=1$ and $\mathrm{t}=2$ showed that there was a significant difference with $\mathrm{p}=0.024$ and ${ }^{*} \mathrm{p}=0.007$, respectively. Student's t-test also used to compare the delta cortisol level during each phase. The results showed significant difference between the delta cortisol level at the end of $t=1$ and at the end of $\mathrm{t}=2\left({ }^{*} \mathrm{p}=0.003\right)$

Clinical and laboratory finding associated with HPA axis suppression almost did not find in patients as shown in Table 3 and Fig. 2.

\section{DISCUSSION}

A total of 15 eligible patients were recruited in this study. The diagnosis of one patient was changed to be lupus nephritis. Cross-reactivity was occurred in 6 patients when measured by ADVIA Centaur Cortisol Assay. It was caused by similarity structure between cortisol and prednisone [21].

The mean cortisol level at $\mathrm{t}=0$ in some patients was lower than others. It was occurred because of genetic variation in HPA axis and receptor variation. Another variation could find in some points of HPA axis system such as at CRH or ACTH synthesis [22]. The history duration and cumulative dose of prednisone were analyzed using Pearson correlation. It showed no significant correlation between the history duration and cumulative dose of prednisone and the cortisol level at $\mathrm{t}=0\left({ }^{*} \mathrm{p}>0.05\right)$. It was occurred because some patients were in alternating phase. Therefore, their cortisol level reached to the normal range [10,22]. One patient had subnormal cortisol level at $\mathrm{t}=0$ because she took $30 \mathrm{mg}$ of prednisone before admission. Another patient had cortisol level higher than normal because he was stress (crying and anxious). Acute stress could induce the releasing of CRH and cortisol as the end product of HPA axis circuit $[9,23]$.

The mean cortisol level at $\mathrm{t}=0$ and $\mathrm{t}=2$ was $11.79 \pm 10.66 \mathrm{mcg} / \mathrm{dL}$ and $1.75 \mathrm{mcg} / \mathrm{dL}$ or decreased $72.92 \%$. Statistical analysis of the cortisol level at $\mathrm{t}=0$ and $\mathrm{t}=1$ showed significant difference with ${ }^{*} \mathrm{p}=0.024$. The suppression was occurred through negative feedback in hypothalamic which suppressed expression of proopiomelanocortin gene at hypophyse and pro-CRH gene at hypothalamic, so releasing of ACTH was inhibited. The deficiency of ACTH caused atrophy of the adrenal gland $[9,24]$. The decrease cortisol level at $t=1$ indicated adrenal suppression which could develop if the morning cortisol level $<3 \mathrm{mcg} / \mathrm{dL}[13,25,26]$. However, the cortisol level at $\mathrm{t}=2$ increased up to $417.60 \%$ from $\mathrm{t}=1 \quad(5.95 \pm 3.33 \mathrm{mcg} / \mathrm{dL})$. Statistical analysis showed significant difference with ${ }^{*} \mathrm{p}=0.007$. The alternating-day regimen could increase cortisol level to normal range or the adrenal suppression at $\mathrm{t}=1$ was reversible. Except in patient with inisial (KY), cortisol level lower than at $\mathrm{t}=1$ received devided dose regimen which suppressed HPA axis higher than single dose $[9,23]$. Statistical analysis also was used to compare the delta cortisol level at the end of induction phase and the end of alternate phase with ${ }^{*} \mathrm{p}=0.003$.

The clinical manifestation such as hypoglycemia, hypotension, weight loss, loss of appetite, and acute dehydration was not found in the patients in this study. Nausea/vomiting and abdominal pain were only found in $7 \%$ after the induction phase caused by prednisone side effect on the digestive tract $[27,28]$.

The limitation of this study was that some patients had cross-reaction with prednisone when using ADVIA Centaur Cortisol Assay. We had to make sure the compliance of patient not to taking prednisone before collecting the sample. Another limitation was that the incidence of NS was rare, so it was difficult to find the subject in short period.

\section{CONCLUSIONS}

HPA axis suppression was occurred in the induction phase which indicated by the decrease of cortisol level $72.92 \%$. The suppression was reversible which was indicated by the increase of the cortisol level at the end of the alternating phase $417.60 \%$. The clinical manifestation only such as nausea/vomiting only found in $11.11 \%$. However, we need do the longer study with many patients to support the result in this study, and further discussion will be needed.

\section{ACKNOWLEDGMENTS}

All subjects are acknowledged for participating in this study. Muhammad Riza Kurniawan, dr., SpA is acknowledgment for constructing comments in manuscript. The authors also thank you to the members of Magister of Clinical Pharmacy, Airlangga University, Surabaya, and Pediatric Nephrology Department, Dr. Soetomo Teaching Hospital Surabaya.

\section{CONFLICTS OF INTEREST}

No conflicts of interest, financial, or otherwise are declared by authors.

\section{REFERENCES}

1. Alatas H, Taralan T, Partini P, Sudung OP. Konsesus Tata Laksana Sindrom Nefrotik Idiopatik pada Anak. Jakarta: Ikatan Dokter Anak Indonesia; 2008. p. 1-18.

2. Lennon R, Watson L, Webb NJ. Nephrotic syndrome in children. Paediatr Child Health 2009;20:36-42.

3. Krishnan RG. Nephronic Syndrome. Paediatr Child Health 2009;22:337-40

4. Trihono PP, Alatas H, Tambunan T, Pardede SO. Tata Laksana Sindrom Nefrotik Idiopatik pada Anak Edisi Kedua. Jakarta: Unit Kerja Koordinasi Nefrologi IDAI; 2012. p. 1-32.

5. Niaudet P. Treatment of Idiopathic Nephrotic Syndrome in Children. Netherland: UpToDate Wolters Kluwer; 2015. p. 1-20.

6. Niaudet P, Boyer O. Idiopathic nephrotic syndrome in children: Clinical aspects. In Avner ED, Harmon WE, Niaudet P, Yoshikawa N, Emma F, Goldstein S, editors. Pediatric Nephrology. $7^{\text {th }}$ ed. New York: Springer; 2016. p. 841-3.

7. Lombel RM, Gipson DS, Hodson EM. Treatment of steroid-sensitive nephrotic syndrome: New guidelines from KDIGO. Pediatr Nephrol 2012;2:1-17.

8. Gupta P, Bhatia V. Corticosteroid physiology and principles of therapy. Indian J Pediatr 2008;75:1-8.

9. Hilal-Dandan R, Brunton LL, editors. Modulation of cardiovascular function. Goodman and Gilman's Manual of Pharmacology and Therapeutics. $2^{\text {nd }}$ ed, New York: McGraw Hill; 2014. p. 770-9. 
10. Chrousos GP. Physiology of Corticotropin-Releasing Hormone. Netherland: UpToDate Wolters Kluwer; 2015. p. 1-15.

11. Shulman DL, Palmert MR, Kemp SF. Adrenal insufficiency: Still a cause of morbidity and death in childhood. Pediatrics 2007;119:e484-94.

12. Liu D, Ahmet A, Ward L, Krshnamoorthy P, Mandelcom E, Leigh R, et al. A practical guide to the monitoring and management of the complications of systemic corticosteroid therapy. Allergy Asthma Clin Immunol J 2013;30:1-25.

13. Miller WL, Fluck CE. Adrenal cortex and its disorder. In Sperling MA, editor, Pediatric Endocrinology $4^{\text {th }}$ ed. Philadelphia,PA: Saunders Elsivier; 2014. p. 537-8.

14. Einaudi S, Bertorello N, Masera N, Farinasso L, Borisone E, Rizzari C, et al. Adrenal axis function after high-dose steroid therapy for childhood acute lymphoblastic leukemia. Pediart Blood Cancer 2008;50:537-41.

15. Soyka LF, Saxena KM. Alternate-day steroid therapy for nephrotic children. JAMA 1965;192:125-30.

16. Leisti S, Koskimies O. Risk of relapse in steroid-sensitive nephrotic syndrome: Effect of stage of post-prednisone adrenocortical suppression. J Pediatr 1983;103:553-8.

17. Sumboonnanonda A, Vingjirad A, Suntorpoch V, Petrarat S. Adrenal function after prednisolone treatment in childhood nephrotic syndrome. J Med Assoc Thai 1994;77:126-9.

18. Abeyagunawardena AS, Hindamarsh P, Trompeter R. Adrenocortical suppression increase the risk of relapse in nephrotic syndrome. Arch Dis Child 2007;92:585-8.

19. Ramachandran R, Jairam A, Bhansali A, Jha V, Gupta K, Sakhuja V, et al. Study of hypothalamic pituitary adrenal axis in patients of membranous nephropathy receiving modified ponticelli regimen. Indian J Nephrol 2015;1:1-5.

20. Krasowski MD, Dress D, Morris CS, Maaskestad J, Blau JL, Ekins S, et al. Cross-reactivity of steroid hormone immunoassays: Clinical significance and two-dimensional molecular similarity prediction. BMC Clin Pathol 2014;33:1-13.

21. Bartels M, De Geus E, Kirschbaum C, Sluyter F, Boomsma DI. Heritability of daytime cortisol levels in children. Behav Genet 2003;33:421-33

22. Furst DF, Saag K G. Glucocorticoid Withdrawal. Ohio: UpToDate Wolters Kluwer; 2015. p. 1-19.

23. Gunnar MR, Donzella B. Social regulation of cortisol levels in early human development. Psychoneuroendocrinology 2002;27:199-220.

24. Barrett EJ. The adrenal gland. In Boron WF, Boulpeb EL, editors, Medical Physiology, A Cellular and Molecular Approach. Philadelphia, PA: Elsevier Saunders; 2012. p. 1057-73.

25. Bancos I, Hahner S, Tomlinson J, Arlt W. Diagnosis and management of adrenal insufficiency. Lancet 2014; 14:70142-1.

26. Taketomo C, Hodding J, Kraus, D. Pediatric Dosage Handbook. $17^{\text {th }}$ ed. Ohio: Lexicomp; 2002, 2013. p. 1569.

27. Lexicomp. Pediatric Drug Information Prednisone. Ohio: UpToDate Wolters Kluwer; 2015. p. 1-14.

28. Donohoue PA. Diagnosis of Adrenal Insuffiency in Children. Ohio: UpToDate Wolters Kluwer; 2014. p. 1-21. 